\title{
A postmortem experience of Indian rock python (Python molurus molurus) that swallowed a whole barking deer
}

\author{
Bhajan Chandra Das ${ }^{1, *}$, Dibyendu Biswas ${ }^{2, *}$, Mohammed Forhad Hossain ${ }^{3}$, Shubhagata Das ${ }^{4}$, \\ Amam Zonaed Siddiki and Abdul Mannan ${ }^{2}$
}

1. Department of Medicine and Surgery, Chittagong Veterinary and Animal Sciences University, Zakir Hossain Road, Khulshi, Chittagong, Bangladesh 2. SA Quaderi Teaching Veterinary Hospital, Chittagong Veterinary and Animal Sciences University, Zakir Hossain Road, Khulshi, Chittagong, Bangladesh 3. Department of Livestock Services, Chittagong, Bangladesh 4. Department of Pathology and Parasitology, Chittagong Veterinary and Animal Sciences University, Zakir Hossain Road, Khulshi, Chittagong, Bangladesh. *Equal contribution to work

Corresponding author: Dibyendu Biswas, e-mail: dibyenducvasu@gmail.com Received: 23-06-2012, Accepted: 14-07-2012, Published online: 06-01-2013

How to cite this article: Das BC, Biswas D, Hossain MF, Das S, Siddiki AZ and Mannan A (2013) A postmortem experience of Indian rock python (Python molurus molurus) that swallowed a whole barking deer, Vet World 6(3):163-165, doi: 10.5455/vetworld.2013.163-165

\begin{abstract}
The object of this study was to report a post mortem findings of a female Indian Rock Python with a length of $406 \mathrm{~cm}$ (13.32 feet) and approximate weight of $60 \mathrm{~kg}$ (including a whole deer that was swallowed by the python), that was brought to the Teaching Veterinary Hospital, Chittagong Veterinary and Animal Sciences University (CVASU) by the Forest Department of Kumira Range Office, Chittagong. The local inhabitants accidently found the python at the forest area of Kumira and they frightenedly injured and killed the snake eventually. The postmortem (PM) examination was performed according to standard protocols. Gross examination revealed bloody discharge was come out through mouth and a couple of skin lacerations observed on the right dorso-lateral part of the abdominal region. The whole barrel-shaped body cavity was opened and whole deer (partially decomposed) was recovered from the stomach. Furthermore, three fractured ribs were found on right thorax. The PM examination team believes that the possible cause of python death was traumatic injury inflicted by the local people.
\end{abstract}

Keywords: barking deer, nematode, rock python

\section{I ntroduction}

The Indian rock python (Python molurus molurus) belongs to reptiles, order-Squamata, suborder- Serpentes, the family Boidae, which contains the world's largest snake species including pythons, boas and anacondas. The lighter colored Indian rock python is native to Indian subcontinent including Bangladesh, Pakistan, Sri Lanka and Nepal. Although endangered, pythons are numerous in the hilly areas of Chittagong and frequently reported to be rescued from human habitats. Barking deer (Muntiacus sp) are also available in Kumira forest range, Sitakundu, Chittagong. The common food habit of python is different types of mammals and birds predominantly in wild situation and whole rat and chicken in zoo condition. It is also noted that larger specimens usually eat animals about the size of a house cat but larger food items are known to take down adult deer and the African rock python has been known to eat antelope but swallowed a whole barking deer by python is quite uncommon and followed by death of python also infrequent. Therefore, the fatal diseases of python are inclusion body diseases [1-3], parvoviral infection [4] and endocardial fibrosarcoma [5]. Viral diseases (paramyxovirus) of the respiratory system have been reported in several species of snakes that outbreaks mortality ranges from 8 to $87 \%[6,7]$ and mortality of reptiles due to bacterial infection upto $75 \%$ [8]. However, malicious injuries to the Indian rock python have been reported in the present study. Postmortem examination was challenging situation and new experience of the expert team.
The present study reveals the actual clue for death of python and as well as study the different gross anatomic measurement.

\section{Materials and Methods}

The PM examination was performed by an expert team with standard protocol [9]. The whole barrelshaped body cavity was opened from mouth to tail and whole deer (partially decomposed) was recovered from the stomach (Fig.2). Heart, liver, spleen, kidney, lungs, trachea along with the whole skeleton and skin were collected separately and preserved for future use. Nematode parasites also were collected and all of them were preserved to be used as teaching and research materials for future.

\section{Results}

The total length of this female Indian Rock Python was $406 \mathrm{~cm}$ (13.32 feet) and approximate weight of $60 \mathrm{~kg}$ (including a whole deer that was swallowed by the python) (Fig.1), Externally, gross examination revealed bloody discharge was come out through mouth and a couple of skin lacerations was observed on the dorso-lateral part of the abdominal region (Fig.3,4). Internally, further gross examination revealed three fractured ribs on right thorax (Fig.5). Large numbers of nematode parasites were also collected from the surface of deer and the pythons' stomach after removal of the deer and measuring the parameters of the following organs (Table-1). Preservation was performed for all the vital organs for further molecular study. 

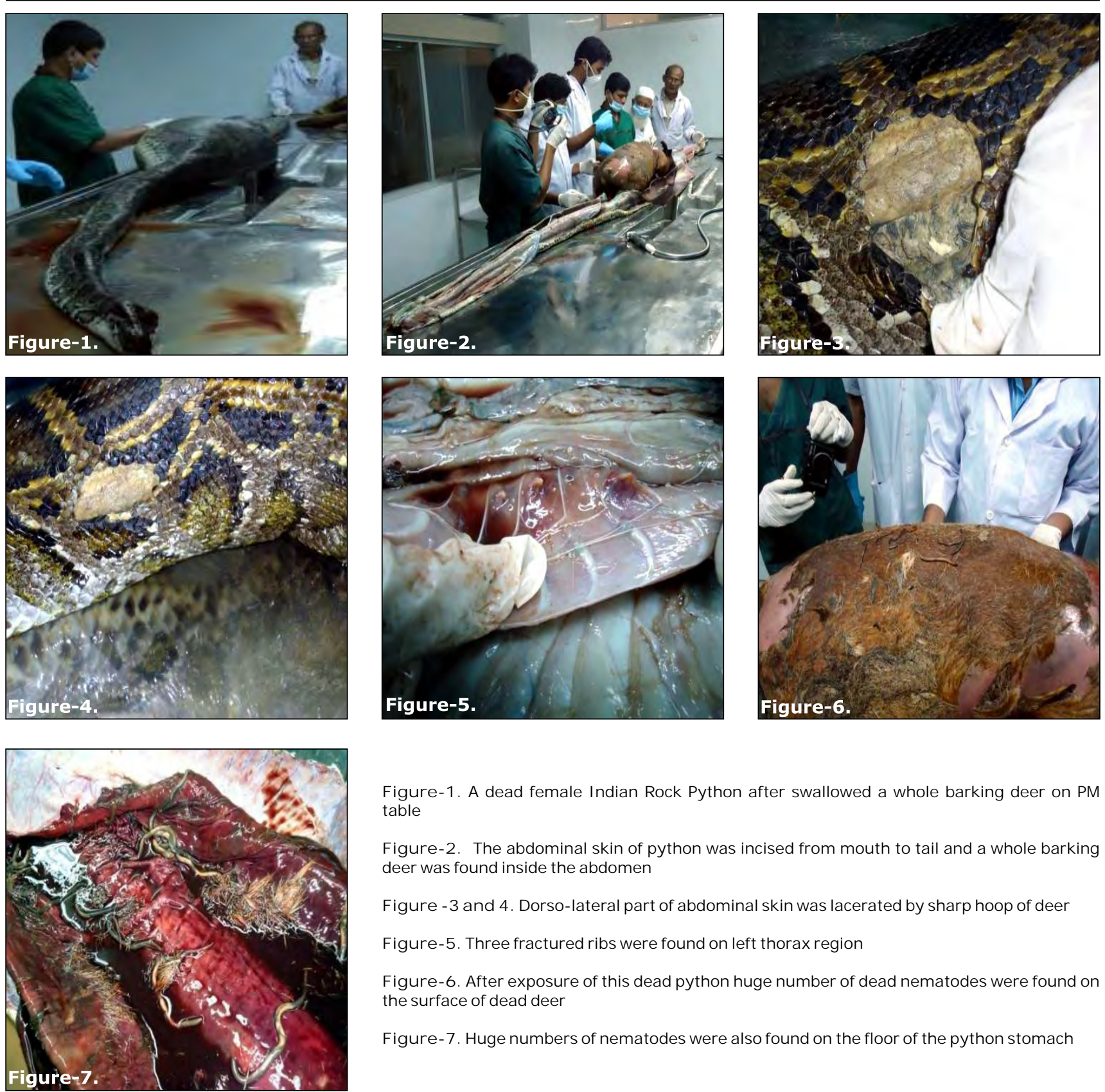

Figure-1. A dead female Indian Rock Python after swallowed a whole barking deer on PM table

Figure-2. The abdominal skin of python was incised from mouth to tail and a whole barking deer was found inside the abdomen

Figure -3 and 4. Dorso-lateral part of abdominal skin was lacerated by sharp hoop of deer

Figure-5. Three fractured ribs were found on left thorax region

Figure-6. After exposure of this dead python huge number of dead nematodes were found on the surface of dead deer

Figure-7. Huge numbers of nematodes were also found on the floor of the python stomach

Table-1. Anatomical measurement of different internal organ of Indian python

\begin{tabular}{lc}
\hline Name of the organs & Length or number \\
\hline Abdominal diameter (Engorged) & $90 \mathrm{~cm}$ \\
Abdominal cavity length & $105 \mathrm{~cm}$ \\
Occipital region & $24 \mathrm{~cm}$ in diameter \\
Tongue & $11 \mathrm{~cm}$ \\
Teeth Nos (Upper jaw) & 14 \\
Outer row & 22 \\
Inner row & 16 \\
Teeth Nos (Lower jaw) & $124 \mathrm{~cm}$ \\
Mandible to abdominal cavity & $94 \mathrm{~cm}$ \\
Trachea & $68 \mathrm{~cm}$ \\
Liver length & $3 \mathrm{~cm}$ \\
Width & $10 \mathrm{~cm}$ \\
Kidney & $16 \mathrm{~cm}$ \\
Cloacal diameter & $70 \mathrm{~cm}$ \\
Lung (length) & $40 \mathrm{~cm}$ \\
Cloacal opening to tip of tail & $11 \mathrm{~cm}$ \\
Heart & $11 \mathrm{~cm}$ \\
Mandible & $16 \mathrm{~cm}$ \\
Skull &
\end{tabular}

\section{Discussion}

The record size for an adult Indian python was about 21 feet $(6.4 \mathrm{~m})$ and most adult individuals are much smaller, rarely exceeding 12 feet $(3.7 \mathrm{~m})$ but in our study, the python length was 13.32 feet $(4.06 \mathrm{~m})$. A typical adult Indian python weighs between 70-120 pounds $(32-55 \mathrm{~kg})$. After swallowing a whole deer, a python can stay for weeks, even months, without another meal. In the present study python swallowed a whole deer was probably due to crisis of food in the forest or it was very hungry.

The main causes of death of snakes in captivity are directly related to their care: improper temperatures, contact with heating and lighting elements, no regular access to water, lack of necessary veterinary care and treatment, careless handling are directly responsible. The bacterial and viral diseases are the most common causes of reptiles death. Viral diseases of respiratory 
system outbreak mortality range from 8 to $87 \%$ and bacterial diseases up to $75 \%$ of mortalities [10]. Inclusion Body Disease (IBD) is the most common and fatal disease of python. Traumatic injury by bitten due to frighten is also a common cause of python death. The present study revealed the python death due to traumatic injury.

Python generally does not attack humans unless startled or provoked, although females protecting their eggs can be aggressive. Attacks on human beings are once more common in South and Southeast Asia, but are now quite rare. However, python killing their owners have been documented [11]. Swallowed a human being is also another reason for killing the python. Only one report was published in news paper that a python killed a woman and half-swallowed cadaver was recovered in south-eastern of Bangladesh. Habitat destruction and hunting for skins to make tourist products contribute to the decline of the Indian python. The present case study was a rare, interesting and also a new experience.

\section{Conclusion}

The possible cause of python death was traumatic injury inflicted by the local people and therefore further awareness programme is essential to prevent similar incidence in the region. The collected sample will help for further molecular study and will enrich our knowledge and improve our laboratory for academic purposes.

\section{Acknowledgements}

We thank Dr. Kazi M. Kamaruddin, Director, Poultry Research and Training Center, Chittagong Veterinary and Animal Sciences University for using his laboratory for postmortem work of this python. Finally, we apologize to those whose work could not be recognized owing to a space limitation.

\section{References}

1. Carlisle-Nowak MS, Sullivan N, Carrigan M, Knight C, Ryan C and Jacobson ER (1998) Inclusion body disease in two captive Australian pythons (Morelia spilota variegate and Morelia spilota spilota). Aust Vet J, 76: 98-100.

2. Cohen HY (2010) Inclusion Body Disease. www. reptileexpert.co.uk

3. Wissman MA (2012) Symptoms for Inclusion Body Disease in Snakes. www.reptilechannel.com.

4. Farkas SL, Zadon Z, Benko M, Essbauer S, Harrach B and Tijssen $\mathrm{P}$ (2004) A parvovirus isolated from royal python (Python regius) is a member of the genus Dependovirus. $J$ Gen Virol, 85 (3): 555-561.

5. Gumber S, Nevarez JG and Cho DY (2010) Endocardial fibrosarcoma in a reticulated python (Python reticularis). $J$ Vet Diagn Invest, 22:1013-1016.

6. Clark HF, Lief FS and Lunger PD (1979) Fer-de-lance virus. A probable paramyxovirus isolated from a reptile. J Gen Virol, 44: 405 .

7. Jacobson E, Gaskin JM and Simpson CF (1980) Paramyxolike virus infection in a rock rattlesnake. J Am Vet Med Assoc, 177: 796.

8. Ippen R and Schroder HD (1977) Zu den Erkrankungen der Reptilien. In Verdandlungsbericht des XIX international Symposiums uber die Erkrankungen der Zootiere. Poznan, Poland. PP 15-29.

9. Balasundara KR, Shekhya GN and Konanur JA (2012) Necrotic stomatitis and haemorrhagic enteritis in an Indian rock python. Eurasian J Vet Sci 28 (1): 60-63.

10. Fowler ME (1986) Zoo and Wild Animal Medicine. $2^{\text {nd }}$ edition. Philadelphia: Saunders, W.B. 109-161.

11. Kaplan M (2012) The Keeping of Large Pythons. http:// www.anapsid.org/coloburm.html 